\title{
EFFECTS OF FOOD SUPPLY CHAIN REGULATION
}

This paper analyses the effects of food supply chain regulation investigating a particular example of the Act No. 395/2009, on Significant Market Power in the Sale of Agricultural and Food Products and Abuse thereof, which came into force in February 2010 in the Czech Republic. The objective of this paper is to explore the impact of this regulation on suppliers, their negotiation position and the retailer-supplier relationship. One hundred and one retail food suppliers were approached via a questionnaire, and the results of the research demonstrate that the Act has improved neither the negotiation position of the majority of suppliers nor the relationship of suppliers with retailers. It was also proven that the Act would not bring any special advantage to small and medium sized enterprises or domestic companies.

Keywords: retail relationships within the food supply chain, effects of legislative regulation, self-regulation

JEL Classifications: A10, L59, L81, K22

DOI: $10.15611 /$ aoe.2018.2.15

\section{INTRODUCTION}

Legislative regulation is one of the very important elements of the external environment that influences the competitiveness of companies. The state, which applies its power through regulatory mechanisms, is one of the important players in this market (Bolotov et al., 2013). The regulators may either help them set the basic conditions of doing business and improve their efficiency, or harm it by excessive rules and administration. This calls also for the regulation of business-to-business relationships, and particularly of the retailer-supplier relationship.

The efficiency of such regulations has been in the centre of concern of both academics and practitioners for a long time. Papers about retail regulation efficacy date back even to the 1930s (Blumenfeld, 1933), and there are many others that follow (e.g. Robson, Rawnsley, 2001; Duffy et al.; 2003; Justo 2008; Larue, Bonroy 2009; Biscourp et al. 2013).

\footnotetext{
* Department of Retailing and Commercial Communications, University of Economics, Prague.
} 
The aim of this paper is to assess one particular example of such a regulation, which is the Czech Act No. 395/2009 on Significant Market Power in the Sale of Agricultural and Food Products and Abuse thereof, known hereafter as "the Act". The objective of this paper is to explore the impact of this regulation on suppliers, their negotiation position and the retailer-supplier relationship, based on a survey among food producers and farmers.

\section{SITUATION IN THE INDUSTRY}

The food supply chain underwent considerable structural changes recently (European Commission, 2013a; Zippel, et al., 2013). "The retailing environment has seen a very significant growth in the size and market dominance of the larger players, with greater store size, [and] increased retailer concentration" (Hollingsworth, 2004). The high concentration of retail companies may be illustrated by the high percentage of the top 5 retail companies with the biggest market share in the country as shown in Figure 1.

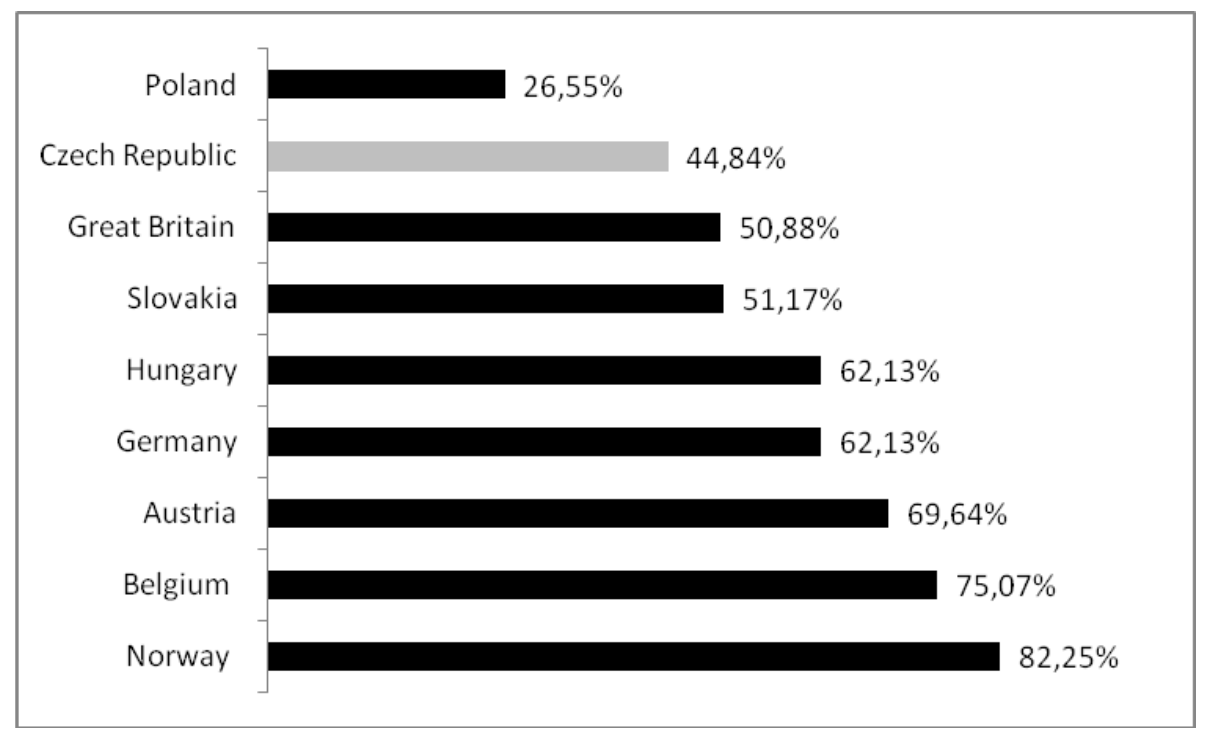

Figure 1. Food sales market share of the top 5 in percentages (selected European countries)

Source: Metro group, 2014. 
It is obvious that especially in some countries, the market is dominated by a few big and powerful retailers. Therefore, "there may be cause for concern that consolidation and globalization can strengthen retailers' ability to exercise market power as both buyers and sellers - dictating higher prices and less variety for consumers, and lower prices for food suppliers" (Kaditi, 2013). Even if small and medium sized enterprises (SMEs) have strengthened their position through the formation of cooperative groups (Ghaderi, Leman, 2013; Caridà, Colurcio, 2014), concerns still prevail that retail suppliers (mainly food producers, but also some farmers delivering directly to retailers) are in a weaker position in relation to their buyers (see e.g. Hogarth-Scott, Parkinson 1993; Marx, Shaffer 2007; Richards et al. 2013 etc.) Therefore, "retailer-supplier relationships have long been of keen interest to marketing academics and practitioners" (Bobot, 2011).

As these tensions between retailers and suppliers may also have an effect on consumers (Dawson, 2000; Bonnet, Dubois, 2010; Wood 2013), a more efficient and fairer functioning of retailing, and of the whole distribution chain is increasingly emphasised (Commission of the European Communities, 2009a), and "the retail trade is subject to substantial regulation in European countries" (Schivardi, Viviano, 2011). Apart from the standard regulation such as antitrust legislation, attention is particularly paid to the regulation of the above-named supplier-retailer relationship within the supply chain, which applies especially to the food retail industry.

To have a recent look at the EU regulation of this area, two communications from the Commission, both accompanied by a matching commission staff working document, were first issued: A better functioning food supply chain in Europe (European Commission, 2009a), Competition in the food supply chain (European Commission, 2009b), the retail market monitoring report Towards more efficient and fairer retail services in the internal market for 2020 (European Commission, 2010a) and On retail services in the internal market (European Commission, 2010b).

The issue is so serious that regulators issued the Green paper on unfair trading practices in the business-to-business food and non-food supply chain in Europe (European Commission, 2013b). This paper initiated a vast discussion on this topic. The findings and conclusions were described in the Communication from the Commission entitled "Tackling unfair trading practices in the business-to-business food supply chain" (European Commission, 2014). The Commission rejected the common regulation of unfair practices within the food supply chain at the EU level, and stressed the principle of self-regulation, mainly by the involvement of corporations 
into voluntary initiatives against unfair practices (Supply Chain Initiative, 2011). However, the EU members should tackle the practices "in an appropriate and proportionate manner, taking into account national circumstances and best practice" (European Commission, 2014).

Individual European countries face this issue very differently. Some of them do not regulate the retailer-supplier relationship at all, some rely on (sometimes functioning) self-regulation, others apply hard-regulation, which also varies very much. Some EU members regulate only some commodities, there are different sanctions described in the acts, there are also big differences in practices considered to be unfair. For more details about the forms of regulation in the EU countries see Stefanelli, Marsden (2012) and Mokrejšová (2013). In this paper, hard regulation of retailer-supplier relationship in the Czech Republic will be shortly presented and its efficiency will be examined.

\section{SITUATION IN THE CZECH REPUBLIC}

The Czech Republic belongs to those countries where hard regulation was chosen to handle unfair practices within the supplier-retailer relationship. Namely, Act No. 395/2009 on Significant Market Power in the Sale of Agricultural and Food Products and Abuse thereof, was adopted. This Act defines the term "significant market power" (SMP) as "a relation between a buyer and a supplier in which, as a result of the situation in the market, the supplier becomes dependent on the buyer with regard to a possibility to supply own goods to consumers, and in which the buyer may impose unilaterally beneficial trade conditions on the supplier" (Czech Republic, 2009). It is worth noting that the significant market power is always attributed to the buyer, i.e. the retailer. The Act describes specific conditions that must be taken into account when assessing the SMP, but in fact the annual net turnover of the corporation exceeding CZK 5 billion (about EUR 185 million) has become the key parameter to decide about it. Consequently, all big retail chains in the market are automatically considered as corporations with SMP and they must not apply the practices specified in the Act.

The Act itself had been discussed for approximately ten years before it was introduced. The necessity to "protect" the supplier companies from unfair practices and coercive behaviour of the retail chains remains one of the main arguments. It was said (Senate, 2009) that mainly SMEs, mostly domestic ones, are in a disadvantageous position when negotiating the 
conditions of their business relationship, and that some of the practices may even bring them to bankruptcy.

Nevertheless, the Act has been criticised both by the retailers and professionals. Insufficient legal quality, the ambiguity of the terms used and the unilateral definition of the subject with significant market power are among its most serious mistakes (Pelikán, 2009; Zadražilová, 2011; Bejček, 2012). As there are contradictory opinions about the Act, the need arose to assess its effect on both business partners. This paper describes the effect on suppliers, other effects are described elsewhere (Mokrejšová, 2013; Filipová et al., 2014).

\section{RESEARCH METHODOLOGY}

Qualitative and quantitative research among suppliers to the retailers was conducted three years after the introduction of the Act. The main part of the research among suppliers was carried out from November 2012 to January 2013. A hard copy of the suppliers' questionnaire was sent to 500 food producers, who are the first beneficiaries of the act, and to 1,900 farmers. There are approximately 10 thousand food producers in the Czech Republic (Ústav zemědělské ekonomiky a informací, 2014), however, the questionnaire was sent only to those producers where it was physically proven that their goods are really directly delivered to retailers.

The questionnaire was based on:

- many in-depth interviews with suppliers,

- consultations with experts (Federation of the Food and Drink Industries of the Czech Republic, the Czech Agrarian Chamber, the Ministry of Industry and Trade of the Czech Republic, Czech Confederation of Trade and Tourism),

- three workshops with suppliers and farmers (April 2011, June 2011 and January 2012),

- and two pilot studies in which the questionnaire was tested (May 2011 and July to September 2011).

The questionnaire had three main parts. The first part comprised of the following questions:

1. "How has your relationship with the retailers changed, since the law came into force?"

2. "How has your position changed, when negotiating with the retailers, since the law came into force?" 
The second part was dealing with unfair practices, their relevance and frequency, and their recent emergence. The third part asked about the main characteristics of the respondents. The questionnaires were filled-in anonymously. In total, 101 questionnaires from 85 producers and 16 farmers who deliver their goods to retailers, were statistically processed. The data presented here are one part of a big umbrella study, which also investigated effects of this Act on retailers (see Mokrejšová, 2013) and farmers (Filipová et al., 2014). The farmers were sent two questionnaires: one concerning their relationship with food producers (who are their main buyers) and the other one asking about their experience with retailers. Altogether, 207 answers from the farmers were returned, but only 16 of them also filled-in the questionnaire concerning retailers, as only very little farmers do deliver directly to retailers.

The hypothesis of the research was stated: The Act has not helped the majority of the suppliers. It also has not given any advantage to SMEs and domestic enterprises. The results of testing this hypothesis are presented below.

Statistical programme SAS 9.2 was used to analyse the primary data. Chisquare tests of independence in contingency tables and Fisher's exact tests were applied. Statistical hypotheses about relative frequencies were also tested and $95 \%$ confidence intervals for the proportion were determined.

\section{RESEARCH RESULTS}

The data from the survey among suppliers are statistically processed bellow as if it was a random sample, even though it is not. However, it is not possible to gain a random sample in this case, and that is why the generalisation of the results is limited. In spite of that, it is worth conducting the statistic tests, even if they might not be as reliable as in the case of random sampling.

\section{a. Change in relationship}

As far as the relationship between the retailers and their suppliers is concerned, only $14.14 \%$ of the respondents claim that their relationship has improved $(95 \%$ confidence interval for the proportion being from $7.3 \%$ to $21 \%$ ); $79.8 \%$ of the respondents answered that their relationship has not changed $(95 \%$ confidence interval for the proportion being from $71.9 \%$ to $87.7 \%$ ). Based on these results, it was tested whether it is possible to statistically prove that the Act has not changed anything with the majority of the suppliers, defining the majority as two thirds. The Null Hypothesis was 
defined as: $67 \%$ of the suppliers have noted no change in the relationship with the retailers and the Alternative Hypothesis as: more than $67 \%$ of the suppliers have noted no change in the relationship with the retailers. The chisquare value is 2.7 and the p-value of the test is 0.0034 , meaning that it was statistically proven that the majority of the suppliers have not recorded any change in the relationship with the retailers after the Act came into force. Even if the majority was defined as $70 \%$, this affirmation would have been proven (p-value 0.0167).

\section{i. SMEs and change in relationship}

As one of the reasons to adopt the law was the support of the SMEs (Senate 2009), it was also tested whether there has been at least any change for them. The answer to Question 1 was therefore tested for its dependence on the fact whether the respondent was from small, medium or big enterprise. The answers follow bellow (Table 1).

Table 1

Change in relationship and size of the enterprise

\begin{tabular}{l|c|c|c}
\hline & No change & Deteriorated & Improved \\
\hline Small & 26 & 4 & 3 \\
\hline Medium & 36 & 2 & 9 \\
\hline Large & 15 & 0 & 2 \\
\hline
\end{tabular}

Source: own research.

The chi-square test of independence was conducted with the following results: chi-square value $4.8902, \mathrm{DF}=4, \mathrm{p}$-value $=0.2988$. The Null Hypothesis about the independence of the answers cannot be refused and therefore it cannot be claimed that respondents would vary in their answers depending on the size of the enterprise. As $56 \%$ of the cells expected counts of less than 5, the chi-square may not be a valid test. This is why Fisher's exact test was also conducted, with p-value 0.4047 , and the same conclusion as the previous test.

To go more into detail, the columns "deteriorated" and "improved" were merged into "any change" to test whether "change" or "no change" in the relationship depends on the size of the enterprise with the following results: chi-square value $1.0442, \mathrm{DF}=2, \mathrm{p}$-value $=0.5933$. The conclusion is the same as above. The rows "small" and "medium" were also merged to form a row "SMEs" and tested with columns "no change" and "any change" in relationship. With chi-square value $0.9872, \mathrm{DF}=1$ and $p$-value 0.3204 , it may be claimed that no dependence could have been statistically proven. As chi- 
square may again not be a valid test, Fisher's exact test was conducted, where the p-value 0.5110 complies with the results above. To sum up, no dependence of change in the relationship with the retailers on the size of the enterprise could have been proven. The assertion that the Act helps SMEs has not been confirmed.

\section{ii. Origin of the enterprise and change in relationship}

Some politicians also vindicated the Act saying that this would help domestic suppliers (Senate 2009). Therefore it was tested whether the answers to Question 1 depend on the origin of the enterprise (domestic or foreign). Table 2 demonstrates the results.

Table 2

Change in relationship and origin of the enterprise

\begin{tabular}{l|c|c|c}
\hline & No change & Deteriorated & Improved \\
\hline Domestic & 48 & 4 & 11 \\
\hline Foreign & 17 & 1 & 2 \\
\hline
\end{tabular}

Source: own research.

The chi-square test of independence (chi-square value $0.7358, \mathrm{DF}=2$, p-value $=0.6922$ ) has not confirmed any dependence. For better validity, Fisher's exact test was conducted with the same conclusion (p-value 0.7961). Again, the "any change" column was created from the last two columns and the table was tested for independence. The results are: chisquare value $0.6937, \mathrm{DF}=1, \mathrm{p}$-value $=0.4049$. P-value of Fisher's exact test is 0.5404 . To conclude, the dependence of the answers to Question 1 on the origin of the enterprise has not been confirmed.

\section{b. Change in negotiation position}

The second question asked the most important issue: "How has your position changed, when negotiating with the retailers, since the law came into force?". It was found that only $9.09 \%$ of the respondents answered that it has improved (95\% confidence interval for the proportion being from $7.3 \%$ to $21 \%$ ); $82.83 \%$ of the respondents marked no change in their negotiation position $(95 \%$ confidence interval for the proportion being from $75.4 \%$ to $90.3 \%$ ). Again, the Null Hypothesis was tested that with $67 \%$ of the suppliers there was no change in their negotiation position and it was confirmed that for more than two thirds of the suppliers, the negotiation position has not changed (the chi-square value is 3.35 , p-value of the test is 0.0004 ). The majority could have been defined even as $70 \%$ (chi-square value 2.79 , p-value 0.0027 ). 


\section{i. SMEs and change in the negotiation position}

As well as with the first question, the dependence of the change in the negotiation position on the size of the enterprise was tested. The results are shown in Table 3.

Table 3

Change in negotiation position and size of the enterprise

\begin{tabular}{l|c|c|c}
\hline & No change & Deteriorated & Improved \\
\hline Small & 28 & 4 & 1 \\
\hline Medium & 38 & 3 & 6 \\
\hline Big & 15 & 0 & 2 \\
\hline
\end{tabular}

Source: own research.

The chi-square test of independence has not confirmed any dependence (chi-square value $4.5823, \mathrm{DF}=4, \mathrm{p}$-value 0.3329). Fisher's exact test was also conducted, with the same conclusion ( $\mathrm{p}$-value 0.3606 ). No dependence can also be proven when merging the "deteriorated" and "improved" column (chi-square value $0.5597, \mathrm{DF}=2$, $\mathrm{p}$-value 0.7559 ). Merging the first two rows into "SMEs" and conducting the chi-square test of independence and Fisher's exact test give the same conclusion (chi-square value $0.3348, \mathrm{DF}=1$, p-value 0.5628, p-value of Fisher's test is 0.7298). To sum up, no dependence was confirmed between the change in negotiation position and the size of the enterprise.

\section{ii. Origin of the enterprise and change in negotiation position}

Again, it was tested whether the change in negotiation position depends on the fact that the supplier is a domestic or a foreign enterprise. Table 4 displays the results.

Table 4

Change in negotiation position and origin of the enterprise

\begin{tabular}{l|c|c|c}
\hline & No change & Deteriorated & Improved \\
\hline Domestic & 52 & 6 & 5 \\
\hline Foreign & 17 & 1 & 2 \\
\hline
\end{tabular}

Source: own research.

As well as in the tests above, no dependence was statistically confirmed. The chi-square test of independence has the following results: chi-square value $0.4561, \mathrm{DF}=2$, $\mathrm{p}$-value 0.7961 . Fisher's exact test $\mathrm{p}$-value is 1.0000 . 
Testing the columns "no change" and "any change" brings the following results. Chi-square test of independence: chi-square value $0.0655, \mathrm{DF}=1, \mathrm{p}$ value 0.5628 ; Fisher's exact test: $\mathrm{p}$-value is 1.0000 . The conclusion is clear: no dependence was confirmed, considering the origin of the suppliers.

\section{c. Food chain members}

There are three main members of the food chain who may negotiate with retailers: farmers, food producers and wholesalers. It was also tested whether there is any dependence of the answers to Questions 1 and 2 on the pertinence of the respondents to these three groups of retail suppliers. In each case, a table of four rows was tested (the respondents also could mark more options, and therefore, the row "mixed" was added to the rows "farmer", "food producer", "wholesaler") which had three columns (improved, deteriorated, no change). The main characteristics of the tests of independence are presented in Table 5.

Table 5

Tests of independence of pertinence to three groups of retail suppliers and answers to Questions 1 and 2

\begin{tabular}{l|c|c|c|c}
\hline & Chi-square value & DF & P-value & Fisher's p-value \\
\hline Relationship & 4.2177 & 6 & 0.6472 & 0.6258 \\
\hline Negotiation position & 5.6144 & 6 & 0.4677 & 0.4575 \\
\hline
\end{tabular}

Source: own research.

Both p-values clearly indicate that it is not possible to reject the Null Hypothesis about independence. It cannot be claimed that the change in both the relationship to retailers and the negotiation position would be dependent on the pertinence to any of the three main groups of retail suppliers.

\section{d. Ratio of retail deliveries}

Finally it was also tested with the two above questions, whether the answers depend on how high a percentage of their production the suppliers deliver to the retailers. If there was found any dependence, it might be necessary to weight the answers of the respondents or to make some conclusions from the answers of those who are more dependent on retailers. The respondents were divided into three groups depending on what percentage of their production they supply to retailers $(0-60 \%, 61-80 \%$, $81-100 \%)$. The main characteristics of the tests of independence of the "changed", "improved" and "deteriorated" tables belonging to Questions 1 and 2 are presented in Table 6. 
Table 6

Tests of independence of change in relationship and negotiation position and percentage of production delivered to retailers (changed, improved, deteriorated)

\begin{tabular}{l|c|c|c|c}
\hline & Chi-square value & DF & P-value & Fisher's p-value \\
\hline Relationship & 6.3448 & 4 & 0.1748 & 0.0918 \\
\hline Negotiation position & 1.6759 & 4 & 0.7951 & 0.7585 \\
\hline
\end{tabular}

Source: own research.

To conclude, the percentage of suppliers' output delivered to retailers was not confirmed as a determinant of suppliers' negotiation position and their relationship with retailers. Even if only two groups (0-60\% and 61-100\%) were defined and the test of "changed" and "not changed" was conducted, no dependence was confirmed (Table 7).

Table 7

Tests of independence of change in relationship and negotiation position and percentage of production delivered to retailers (changed, not changed; $0-60 \%, 61-100 \%$ )

\begin{tabular}{l|c|c|c|c}
\hline & Chi-square value & DF & P-value & Fisher's p-value \\
\hline Relationship & 0.2033 & 1 & 0.6521 & 0.7656 \\
\hline Negotiation position & 0.0204 & 1 & 0.8863 & 1.0000 \\
\hline
\end{tabular}

Source: own research.

\section{e. Interim Conclusion}

The majority of the surveyed suppliers say that both their relationship to retailers and their negotiation position have not changed since the Act came into force. No statistically significant dependence was confirmed of any difference in the answers of SMEs, domestic enterprises, farmers, food producers or wholesalers. There was even no statistically significant dependence found on how much of their production the suppliers deliver to retailers. To sum up, the Act has not helped the majority of suppliers, and it also cannot be stated that it would support SMEs or domestic enterprises.

\section{f. Unfair practices}

The second big part of the questionnaire was dealing with unfair practices banned by the Act. The suppliers were asked how serious they consider each practice to be, why they think the practice harms their enterprise and how often they come across such a practice. Table 8 presents the practices ordered from the worst to the least harmful from the point of view of the suppliers (who rated them from 0 to 5 ). 
Table 8

Unfair practices banned by the Act

\begin{tabular}{l|c|c|c|c|c|c|c}
\hline \multicolumn{1}{c|}{ Practice } & Mark & $\begin{array}{c}\text { Standard } \\
\text { deviation } \\
\text { of the } \\
\text { mark }\end{array}$ & $\begin{array}{c}\text { Pro- } \\
\text { portion }\end{array}$ & $\begin{array}{c}\text { Lower } \\
\text { limit } \\
\mathbf{9 5 \% )}\end{array}$ & $\begin{array}{c}\text { Upper } \\
\text { limit } \\
\mathbf{9 5 \% )}\end{array}$ & $\begin{array}{c}\text { At } \\
\text { least } \\
\text { once }\end{array}$ & $\begin{array}{c}\text { Meeting } \\
\text { the } \\
\text { practice } \\
\text { now }\end{array}$ \\
\hline Below-cost selling & 3.38 & 1.7315 & $45.35 \%$ & $34.80 \%$ & $55.90 \%$ & $89.58 \%$ & 33 \\
\hline $\begin{array}{l}\text { Transmitting retailers' penalties on } \\
\text { their suppliers without proven fault } \\
\text { of the supplier }\end{array}$ & 3.35 & 1.6625 & $21.98 \%$ & $13.50 \%$ & $30.50 \%$ & $77.08 \%$ & 30 \\
\hline $\begin{array}{l}\text { Sudden termination of business } \\
\text { relationship }\end{array}$ & 3.33 & 1.7168 & $24.42 \%$ & $15.30 \%$ & $33.50 \%$ & $77.66 \%$ & 24 \\
\hline $\begin{array}{l}\text { Requiring retroactive discounts } \\
\text { Automatic subtraction of losses, } \\
\text { fines and sanctions for late delivery } \\
\text { or unsatisfactory state of the goods } \\
\text { from the invoice }\end{array}$ & 3.17 & 1.6787 & $54.88 \%$ & $44.10 \%$ & $65.60 \%$ & $85.71 \%$ & 33 \\
\hline $\begin{array}{l}\text { Requiring an audit of production } \\
\text { paid by the supplier }\end{array}$ & 2.15 & 1.5655 & $\mathbf{6 0 . 0 0 \%}$ & $\mathbf{4 9 . 6 0 \%}$ & $\mathbf{7 0 . 4 0 \%}$ & $89.47 \%$ & 40 \\
\hline $\begin{array}{l}\text { Clearing invoices without written } \\
\text { permission of the supplier }\end{array}$ & 2.82 & 1.7195 & $\mathbf{6 2 . 0 3 \%}$ & $\mathbf{5 1 . 3 0 \%}$ & $\mathbf{7 2 . 7 0 \%}$ & $86.02 \%$ & 44 \\
\hline $\begin{array}{l}\text { Returning unsold goods to supplier } \\
\text { Payment period longer than 30 days }\end{array}$ & 2.46 & 1.3577 & $33.70 \%$ & $24.00 \%$ & $43.40 \%$ & $91.58 \%$ & 24 \\
\hline $\begin{array}{l}\text { Refusal to write the name of the } \\
\text { producer on the private-label } \\
\text { product }\end{array}$ & 1.4300 & $\mathbf{6 6 . 2 5 \%}$ & $\mathbf{5 5 . 9 0 \%}$ & $\mathbf{7 6 . 6 0 \%}$ & $97.89 \%$ & 41 \\
\hline
\end{tabular}

Source: own research.

Below-cost pricing is the practice considered to be the worst of all, whereas refusal to write the name of the producer on the private-label product does not seem to be a big problem for the suppliers. The highest standard deviation was found with the practice of requiring the audit of production to be paid by the supplier, meaning that the answers of the respondents differ most of all regarding this practice. The next three columns display the percentage of the suppliers who had come across the practice "often" or "very often" before the Act came into force. Those ones were marked in bold where it was statistically confirmed that the majority of the suppliers, defined by $50 \%$, had met the practice "often" or "very often" (pvalue $<0.05$ ). The majority of suppliers had therefore faced a long payment period (however, they were legal and mirrored in the time value of money) and the relative impossibility to influence, which claims of retailers are justifiable (and may be therefore set-off) and which are not. It was also analysed what proportion of the respondents experienced the practice at least once. The next column of Table 8 demonstrates that with all of the practices, $65 \%$ of the suppliers or more had to face each practice at least once. 
However, interest was also focused on the changes in the practices after the law was introduced. As far as the qualitative research is concerned, the 2011 pilot study (Zadražilová, 2011) was fully confirmed: almost nothing has changed in the practices. The payment period was shortened, however the price of the delivery was reduced according to the time value of money. There are no more product returns, however the price of the goods diminished based on the percentage of product returns from previous years. At least, the suppliers won higher price certainty in this case (previously they had not known in advance how much the products returned would cost, now they obtain a lower price, but it is more certain). To find out more about the qualitative results of this 2011 pilot study, see Zadražilová (2011).

In a big 2012/2013 study, it was also investigated whether suppliers even now meet the practices in the form as they had appeared before the law was passed. Unfortunately, many respondents did not answer this question, which is why there is no sense in counting percentages. However, as the last column of Table 8 illustrates, suppliers are still facing these practices even if they are banned by the Act. To conclude, the Act has not helped the majority of the suppliers.

\section{g. Hypothesis testing}

Based on the results of the survey described above, it is now possible to test the hypothesis of this paper: The Act has not helped the majority of the suppliers. It also has not given any advantage to SMEs and domestic enterprises.

It was statistically confirmed that the Act has not helped the majority of the suppliers, in fact the statistic tests disclosed that more than $70 \%$ of the suppliers say that there was no change in relationship with the retailers and in their negotiation position when dealing with retailers. The suppliers also still face the practices banned by the Act. Thus the first part of the hypothesis has been confirmed.

The second part of the hypothesis can be neither supported nor refused. We have shown that no dependence could be statistically supported between the size/origin of the enterprise and answers to the questions, but this does not mean that there is absolutely no dependence. We can at least say that it cannot be confirmed that SMEs and domestic firms would anyway benefit from the Act. We would expect that if the Act helped SMEs and domestic enterprises, there would be some convincing statistical dependence found, which was not the case. 


\section{DISCUSSION}

As the results of the study above show, the Act did not make much sense for the retail suppliers. It has not helped them improve their negotiation position or their relationship with retailers and many unfair practices have only been changed so that they cannot be punished by the Act. It must be admitted that the Act helped shorten the payment period to 30 days and removed returns of unsold goods back to the supplier, but this was mainly offset by lower price. Moreover, these two practices are not considered by the suppliers to be as severe, as can be seen in Table 8. As far as the application of the law is concerned, although nine administrative proceedings had been started (Department of International and External Relations, 2015), only two decisions were already made (Office for the Protection of Competition, 2015), one of which was rejected by the court and returned for a further investigation (Office for the Protection of Competition, 2016).

As there were many groups criticising the Act (retailers, politicians, academics, many food producers due to its inefficiency), the Act was amended at the beginning of 2016 (Czech Republic, 2016). A clearer definition of SMP confirmed the existing practice that a retailer having SMP is in the position of SMP towards all its suppliers (even big transnational corporations). The amendment also introduced obligatory contract conditions of the retailer-supplier relationship and omitted the concrete list of unfair practices included in the attachment of the former Act. It is still too early to assess its impact, it can be only stated that another four administrative proceedings have been started (Press Department, 2017a; Press Department 2017b). The efficiency of the amendment should be subject to further research. The authors of this paper are convinced that the amendment could perhaps improve the negotiation position of the suppliers, however, it will not positively influence the relationship between suppliers and retailers, and only a good relationship between the contract parties can lead to a sustainable win-win situation.

Is there any solution to the issue? There are several directions which retailer-supplier relationships in the Czech Republic could take:

- the amendment proves to be efficient and will be applied;

- the amendment does not prove to be efficient, but it will be applied however, as there will be no political will to change it;

- the amendment does not prove to be efficient and will be replaced by other legislative regulation;

- common European regulation will be adopted; 
- private regulation (self-regulation of a group of retailers) will play a key role (see Havinga, 2006);

- individual self-regulation in the form of responsible behaviour towards stakeholders (including suppliers) will be a part of a solution (see Chung et al. 2006; Fisher 2013; Mokrejšová, 2013); this suggestion is based on the idea that "close cooperation with suppliers can lead to an improvement in companies' competitiveness" (Ratajczak-Mrozek, Malys, 2012) and is therefore advantageous for retailers;

- regulators will vote for no regulation relying on the "invisible hand of the market" (Smith, 1976).

A problem of the legislative path of handling the retailer-supplier relationship in the Czech Republic is that it has become a big lobby issue and it is a good topic to attract voters as big retailers are perceived to be "public enemies" and punishing enemies brings political advantage. This topic is therefore not solved rationally using economic theory, but it is used in political campaigns, mainly without the aim to solve the situation itself. Moreover, the contractual parties often misuse media to exaggerate the issue providing them with misleading information. It is interesting that retailers and their suppliers are at the same time able to cooperate on mutual projects, e.g. the Czech-Slovak ECR Initiative (ECR, 2017), however when it comes to this topic, they automatically consider the second contractual party to be an enemy.

Concerning the EU regulation based on the initiative from the Ministers of Agriculture of the Visegrad Group, the issue of common regulation has recently started to be discussed in some bodies of the EU (European Economic and Social Committee, 2016). However, concerning the EU processes, a fast decision cannot be assumed, also in light of Brexit.

As far as private self-regulation is concerned, the "Supply Chain Initiative" already exists, which is a "joint initiative launched by seven EUlevel associations with the aim to increase fairness in commercial relations along the food supply chain. The members agreed on a set of Principles of Good Practice which contain a list of examples of fair and unfair practices in vertical trading relationships" (Supply Chain Initiative, 2011). However, almost all Czech retailers with SMP are its members (Iniciativa pro férový obchod, 2016) and it does not seem to really work. The same can be claimed about individual self-regulation, as some Czech retailers already have their own codes of conduct (Mokrejšová, 2013).

The problem is that the demand for responsible retailers and suppliers is missing. Consumers do not reflect this topic in their choice of goods and 
retailers. They are only interested in it from the political point of view, but not in their real buying behaviours. If there existed pressure from consumers on both retailers and their suppliers to handle fairly their contracts, as it was e.g. with child labour (Rauscher et al., 2008), or in the case of fair trade (Becchetti et al., 2013), it could help to improve the situation (this cannot be the only remedy, but it could contribute to the solution). Consumer education using correct information conducted by non-governmental organisations with the help of the state would be needed to support consumers in their everyday fair choice.

\section{CONCLUSIONS}

This paper focused on the relationships within the supplier-retailer chains in the Czech Republic. These relationships are characterised by a certain tension caused by the highly competitive environment in the Czech retail market. This situation often leads to pressure from stronger entities on their business partners which should ensure them some advantages, leading mainly to lowering the costs of the stronger partner. The regulators of the Czech retail market have assessed the situation as unsustainable and decided to tackle it by hard regulation, hence issuing an act that should regulate the supplier-retailer relationship. The Act No. 395/2009 was passed.

With respect to the purpose of the Act intended by the regulators, the negotiation position of the suppliers should have strengthened and the unfair practices defined by the Act should not occur any more. To assess whether this goal of the Act has been achieved, research focusing on the effect of the Act has been conducted. The companies supplying food to retail chains in the Czech Republic were asked about their opinion about the impact of the Act. The results of this survey, presented in the text above, confirm quite unequivocally the negligible effect of this legislation, which did not reach its intended purpose. Neither the negotiation position of the suppliers nor the relationship between suppliers and buyers have improved. Moreover, it cannot be even proven that the Act would give any advantage to the SMEs or domestic companies. Although the Act shortened the payment period and stopped returns of unsold goods to suppliers, this was reflected in lowering the price of the goods for suppliers. Other practices were slightly changed, so that the Act is being observed.

Other solutions of the retailer-supplier relationship must be sought to improve this situation. It seems that such a complex issue must be tackled from many points of view, so a combination of smart regulation and self- 
regulation supported by consumer pressure was proposed. It is a subject for further research as to whether the amendment to the Act will be considered a smart regulation or not.

\section{REFERENCES}

Becchetti, L., Castriota, S., Michetti, M., The Effect of Fair Trade Affiliation on Child Schooling: Evidence from a Sample of Chilean Honey Producers, "Applied Economics", vol. 45, issue 25, 2013.

Bejček, J., Úprava tzv. významné tržní síly: přirozený krok k ochraně spotřebitele a slabšího, nebo „papirový tygr" (a škůdce soutěže a spotřebitele)? [Legislation of So-called Significant Market Power: A Natural Step towards Protecting the Consumer and the Weaker, or "Paper Tiger" (Harming Competition and the Consumer)?], "Bulletin advokacie" ["Bulletin of advocacy"], no. 7-8, pp. 15-25, 2012.

Biscourp, P., Boutin, X., Verge, T., The Effects of Retail Regulations on Prices: Evidence from the Loi Galland, "Economic Journal", vol. 123, no. 573, pp. 1279-1312, 2013.

Blumenfeld, J., Retail Trade Regulations and Their Constitutionality, "California Law Review", vol. 22, no. 1, pp. 86-106, 1933.

Bobot, L., Functional and Dysfunctional Conflicts in Retailer-Supplier Relationships, "International Journal of Retail \& Distribution Management", vol. 39, no. 1, pp. 25-50, 2011.

Bolotov, I., Čajka, R., Gajdušková, K., Economic Development of the EU New Member States. The Impact of the Crisis and the Role of the Single European Currency, "Oeconomica", Praha, 2013.

Bonnet, C., Dubois, P., Inference on Vertical Contracts between Manufacturers and Retailers Allowing for Nonlinear Pricing and Resale Price Maintenance, "The Rand Journal of Economics", vol. 41, no. 1, pp. 139-164, 2010.

Braşoveanu, I. V., Braşoveanu, L. O., Maşcu, S., Comparative Analysis of Consumer Protection, Considering the Globalisation and Technological Changes, within Member States of the European Union, "Amfiteatru Economic", vol. XVI, no. 36, pp. 517-534, 2014.

Caridà, A., Colurcio, M., Collaborative Innovation in Food SMEs: A Practice Approach, "Archives of Business Research", vol. 2, no. 4, pp. 138-149, 2014.

Chung, J., Sternquist, B., Chen, Z., Retailer-Buyer Supplier Relationships: The Japanese Difference, "Journal of Retailing", vol. 82, no. 4, pp. 349-355, 2006.

European Economic and Social Committee, Report from the Commission to the European Parliament and the Council on unfair business-to-business trading practices in the food supply chain, COM(2016) 32 final, Brussels, 2016.

Czech Republic, The Act No. 395/2009 Coll. on Significant Market Power in the Sale of Agricultural and Food Products and Abuse thereof, Translated by the Office for the Protection of Competition, 2009. 
Czech Republic, The Act No. 50/2016 Coll. Amending the Act No. 395/2009 Coll. On Significant Market Power in the Sale of Agricultural and Food Products and Abuse thereof, 2016.

Dawson, J., Viewpoint: Retailer Power, Manufacturer Power, Competition and Some Questions of Economic Analysis, "International Journal of Retail \& Distribution Management", vol. 28, no. 1, pp. 5-8, 2000.

Department of International and External Relations, Press Release 15/023/HS012, Office for the Protection of Competition, 2015.

Duffy, R., Fearne, A., Hornibrook, S., Measuring Distributive and Procedural Justice: An Exploratory Investigation of the Fairness of Retailer-Supplier Relationships in the UK Food Industry, "British Food Journal”, vol. 105, no. 10, pp. 682-694, 2003.

ECR, Členové, Česko-slovenská inicitativa ECR [Members, Czech-Slovak Initiative], 2017

European Commission, A Better Functioning Food Supply Chain in Europe, Communication from the Commission, $\operatorname{COM}(2009) 591$ final, Commission of the European Communities, Brussels, 2009a.

European Commission, Competition in the Food Supply Chain, Commission staff working document, SEC(2009) 1449, Commission of the European Communities, Brussels, 2009b.

European Commission, Retail Market Monitoring Report "Towards More Efficient and Fairer Retail Services in the Internal Market for 2020", Report from the Commission. $\operatorname{COM}(2010) 355$ final, Commission of the European Communities, Brussels, 2010a.

European Commission, On Retail Services in the Internal Market Accompanying Document to the Report on Retail Market Monitoring: Towards More Efficient and Fairer Retail Services in the Internal Market for 2020, Commission staff working document. SEC(2010)807 final, Commission of the European Communities, Brussels, $2010 \mathrm{~b}$.

European Commission, Setting up a European Retail Action Plan, Communication from the Commission, $\operatorname{COM}(2013) 36$ final, Commission of the European Communities, Brussels, 2013a.

European Commission, Green Paper on Unfair Trading Practices in the Business-to-Business Food and Non-food Supply Chain in Europe, COM(2013) 37 final, Commission of the European Communities, Brussels, 2013b.

European Commission, Tackling Unfair Trading Practices in the Business-to-Business Food Supply Chain. Communication from the Commission, COM(2014) 472 final, Commission of the European Communities, Brussels, 2014.

Filipová, A. Mokrejšová, V., Zeman, J., Significant Market Power Act Efficiency, “Acta academica karviniensia", vol. XIV, no. 4, pp. 18-25, 2014.

Fischer, C., Trust and Communication in European Agri-food Chains, "Supply Chain Management”, vol. 18, no. 2, pp. 208-218, 2013.

Ganescu, M. C., Asandei, M., Gangone, A., Chirilă, C., Performance Determinants for Responsible Supply Chain Management in the European Emerging Countries, "Amfiteatru Economic", vol. XV, no. 33, pp. 155-169, 2013. 
Ghaderi, H., Leman, Z., Horizontal Collaboration in Purchasing: A Successful Case from Small and Medium Enterprises, "African Journal of Business Management", vol. 7, no. 10, pp. 750-753, 2013.

Havinga, T., Private Regulation of Food Safety by Supermarkets, "Law \& Policy", vol. 28, no. 4, pp. 515-533, 2006.

Hogarth-Scott, S., Parkinson, S. T., Retailer-Supplier Relationships in the Food Channel: A Supplier Perspective, "International Journal of Retail \& Distribution Management", vol. 21, no. 8, pp. 11-19, 1993.

Hollingsworth, A., Increasing Retail Concentration: Evidence from the UK Food Retail Sector, "British Food Journal", vol. 106, no. 8, pp. 629-638, 2004.

Iniciativa pro férový obchod, Připojili se [Fair Trade Initiative, Members], IPFO, 2016.

Justo de, J. M., Efficiency and Regulation in the Spanish Hypermarket Retail Trade, "International Journal of Retail \& Distribution Management", vol. 36, no. 1, pp. 71-88, 2008.

Kaditi, E. A., Market Dynamics in Food Supply Chains: The Impact of Globalization and Consolidation on Firms' Market Power, “Agribusiness”, vol. 29, no. 4, pp. 410-425, 2013.

Larue, B., Bonroy, O., Seemingly Competitive Food Retail Regulations: Who Do They Really Help?, "Canadian Journal of Agricultural Economics", vol. 57, no. 3, pp. 305-324, 2009.

Maloni, M. J., Brown, M. E., Corporate Social Responsibility in the Supply Chain: An Application in the Food Industry, Journal of Business Ethics, vol. 68, no. 1, pp. 35-52, 2006.

Marx, L. M., Shaffer, G., Upfront Payments and Exclusion in Downstream Markets, "The Rand Journal of Economics", vol. 38, no. 3, pp. 823-843, 2007.

Metro Group, Concentration of Companies in European Food Retailing 2012, Metro retail compendium, 2014.

Mokrejšová, V., Regulace dodavatelsko-odběratelských vztahů v potravinářském řetězci [Regulation of Retailer-Supplier Relationships within the Food Chain], Dissertation, Praha 2013.

Office for the Protection of Competition, Sbirky rozhodnuti [Collection of Decisions], 2015.

Office for the Protection of Competition, Soudni prezkum rozhodnutí [Judicial Review of the Decision], 2016.

Pelikán, R., Zákon o významné tržní síle - legislativni 'Dada' směruje do praxe [Significant Market Power Act - The Legislative 'Dada' Goes into Practice]. Antitrust Revue, Praha 2009.

Press Department, Press Release 17/019/VTS004, Office for the Protection of Competition, $2017 \mathrm{a}$.

Press Department, Press Release 17/022/VTS004, Office for the Protection of Competition, $2017 \mathrm{~b}$.

Ratajczak-Mrozek, M., Malys, L., Supply Chain Cooperation and Company Performance, "Argumenta Oeconomica", vol. 29, no. 2, pp. 89-107, 2012. 
Rauscher, K. J., Runyan, C. W., Schulman, M. D., Bowling, J. M., US Child Labor Violations in the Retail and Service Industries: Findings From a National Survey of Working Adolescents, "American Journal of Public Health", vol. 98, issue 9, pp. 1693-1699, 2008.

Richards, C., Bjørkhaug, H., Lawrence, G., Hickman, E., Retailer-driven Agricultural Restructuring-Australia, the UK and Norway in Comparison, "Agriculture and Human Values", vol. 30, no. 2, pp. 235-245, 2013.

Robson, I., Rawnsley, V., Co-operation or Coercion? Supplier Networks and Relationships in the UK Food Industry, "Supply Chain Management", vol. 6, no. 1, pp. 39-48, 2001.

Schivardi, F., Viviano, E., Entry Barriers in Retail Trade, "Economic Journal", vol. 121, no. 551, pp. 145-170, 2011.

Senate, The Senate of the Parliament of the Czech Republic - Transcript of the 8th Meeting, Praha, 2009.

Smith, A., The Theory of Moral Sentiments, The Glasgow Edition of the Works and Correspondence of Adam Smith, vol. 7. Oxford University Press, 1976.

Stefanelli, J., Marsden, P., Models of Enforcement in Europe for Relations in the Food Supply Chain, British Institute of International and Comparative Law, London, 2012.

Supply Chain Initiative, Vertical Relationships in the Food Supply Chain: Principles of Good Practice, Brussels, 2011.

Ţigu, G., Ţuclea, C.-E., Vrânceanu, D.-M., Vasile, D.-C., The Social Responsibility of Retailers Through the Eyes of Students of a Commerce Faculty - A Qualitative Approach, "Amfiteatru Economic", vol. XVI, no. 35, pp. 73-87, 2014.

Ústav zemědělské ekonomiky a informací, Panorama potravinářského průmyslu 2013, Ministerstvo zemědělství ČR, [Institute of Agricultural Economics and Information, Panorama of the Food Industry 2013, The Ministry of Agriculture of the Czech Republic] Praha, 2014.

Wood, S., Revisiting the US Food Retail Consolidation Wave: Regulation, Market Power and Spatial Outcomes, “Journal of Economic Geography”, vol. 13, no. 2, pp. 299-326, 2013.

Zadražilová, D., et.al., Společenská odpovědnost podniků. Transparentnost a etika podnikání [Corporate Social Responsibility. Transparency and Business Ethics]. C. H. Beck, Praha, 2010.

Zadražilová, D., a kol., Udržitelné podnikání [Sustainable Business], „Oeconomica”, Praha 2011.

Zippel, C., Wilkinson, J., Vogler, T., The Influence of Private Labels on Retailer Cooperation, “Australasian Marketing Journal”, vol. 21, no. 4, pp. 271-277, 2013.

Received: July 2015, revised: April 2017 